\title{
Interaction Between the Rubidium Cation and [2.2.2] Paracyclophane: Experimental and Theoretical Study
}

\author{
Emanuel Makrlík, ${ }^{1,}{ }^{*}$ Stanislav Böhm, ${ }^{2}$ David Sýkora, ${ }^{2}$ \\ Magdalena Kvíčalová ${ }^{1}$ and Petr Vaňura ${ }^{2}$ \\ ${ }^{1}$ Faculty of Environmental Sciences, Czech University of Life Sciences, Kamýcká 129, 16521 Prague 6 - Suchdol, \\ Czech Republic \\ ${ }^{2}$ University of Chemistry and Technology, Prague, Technická 5, 16628 Prague 6, Czech Republic \\ *Corresponding author: E-mail: makrlik@centrum.cz \\ Phone: +420 376594672
}

Received: 21-06-2017

\begin{abstract}
By means of electrospray ionization mass spectrometry (ESI-MS), it was evidenced experimentally that the rubidium cation $\left(\mathrm{Rb}^{+}\right)$reacts with the electroneutral [2.2.2] paracyclophane ligand $\left(\mathrm{C}_{24} \mathrm{H}_{24}\right)$ to form the cationic complex $\left[\mathrm{Rb}\left(\mathrm{C}_{24} \mathrm{H}_{24}\right)\right]^{+}$. Moreover, applying quantum chemical calculations, the most probable conformation of the proven $\left[\mathrm{Rb}\left(\mathrm{C}_{24} \mathrm{H}_{24}\right)\right]^{+}$complex was solved. In the complex $\left[\mathrm{Rb}\left(\mathrm{C}_{24} \mathrm{H}_{24}\right)\right]^{+}$having a symmetry very close to $C_{3}$, the "central" cation $\mathrm{Rb}^{+}$, fully located in the cavity of the parent [2.2.2]paracyclophane ligand, is coordinated to all three benzene rings of [2.2.2] paracyclophane via cation- $\pi$ interaction. Finally, the binding energy, $E(\mathrm{int})$, of the considered cation- $\pi$ complex $\left[\mathrm{Rb}\left(\mathrm{C}_{24} \mathrm{H}_{24}\right)\right]^{+}$was evaluated as $-99.3 \mathrm{~kJ} / \mathrm{mol}$, confirming the formation of this fascinating complex species as well. This means that the [2.2.2]paracyclophane ligand can be considered as a receptor for the rubidium cation in the gas phase.
\end{abstract}

Keywords: [2.2.2] Paracyclophane; Rubidium cation; Cation $-\pi$ interaction; DFT calculations; Structures.

\section{Introduction}

It is well-known that $\pi$-prismands and certain hydrocarbon cyclophanes are capable of forming $\pi$-complexes with some small metal cations, where benzene rings act as $\pi$-donors for the respective complexes. ${ }^{1}$ This fascinating complexation behavior is especially effective for [2.2.2] paracyclophane and related structures. ${ }^{2,3}$ Pierre et al. ${ }^{3}$ have reported the preparation of the silver triflate complex of [2.2.2]paracyclophane and claimed that it was the first member of a new class of compounds; owing to the complexation properties, they proposed the name $\pi$-prismand for such hydrocarbon cyclophanes. Furthermore, Vögtle et al. ${ }^{4}$ have shown that concave hydrocarbon cyclophanes can extract certain metal ions from an aqueous phase into a nonpolar phase. They have tested these hydrocarbons as ionophores and have shown that PVC-[2.2.2]paracyclophane membranes demonstrated remarkable sensitivity toward the univalent silver cation. ${ }^{4}$ Recently, the first-principles model of Fermi resonance in the alkyl $\mathrm{CH}$ stretch region has been applied to 1,2-diphenylethane and [2.2.2] paracyclophane. ${ }^{5}$ Finally, the role of the metal formal charge in the cation- $\pi$ interactions has been evaluated with relativistic DFT methods involving a versatile $\pi$-cryptating structure, namely [2.2.2] paracyclophane. ${ }^{6}$

Cation $-\pi$ interaction refers to the noncovalent attraction between a cation and a $\pi$-system. ${ }^{7,8}$ Its strength is often comparable with the interaction between a cation and traditional ligands, including water, alcohols, and amines. As a result of this cation- $\pi$ interaction, there are extraordinarily important driving forces in molecular recognition processes in many biological and artificial systems. ${ }^{9-12}$ The considered cation- $\pi$ interaction is a well-established phenomenon in the gas phase, as well as in the solid state, ${ }^{13-19}$ and is known to play very important role in the stabilization of tertiary structures of various proteins. ${ }^{20}$

We must emphasize that the cation $-\pi$ interactions of [2.2.2] paracyclophane $\left(\mathrm{C}_{24} \mathrm{H}_{24}\right.$; see Figure 1) with the 


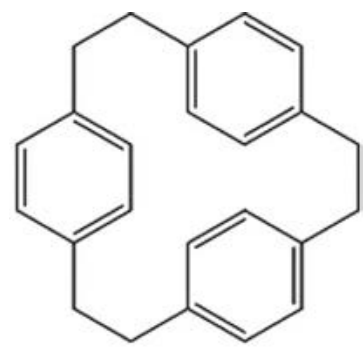

Figure 1. Structural formula of [2.2.2] paracyclophane $\left(\mathrm{C}_{24} \mathrm{H}_{24}\right)$.

"soft" cations $\mathrm{Ag}^{+3,21,22}$ and $\mathrm{Tl}^{+23}$ have been investigated and proven quite unambiguously.

However, up to now, interaction of the mentioned electroneutral [2.2.2]paracyclophane ligand with a very bulky cation has not been studied and [2.2.2] paracyclophane was considered to be a receptor for the transition metal cations. ${ }^{6}$ On the other hand, in our previous work we show, that paracyclophane [2.2.2] could also encapsulate light alkali metal cation $\mathrm{Na}^{+} .{ }^{24}$

Therefore, in the present work, electrospray ionization mass spectrometry (ESI-MS) was applied as an experimental technique for characterization of the cation- $\pi$ interaction between the very voluminous heavy univalent rubidium cation $\left(\mathrm{Rb}^{+}\right)$and this [2.2.2] paracyclophane ligand in the gas phase. In this context we must state that the cation $\mathrm{Rb}^{+}$was chosen for the present study especially for the sake of an expected fascinating structure of the resulting cationic complex involving the [2.2.2] paracyclophane ligand. Furthermore, by means of quantum chemical DFT calculations, the most probable conformation of the experimentally evidenced cationic complex $\left[\mathrm{Rb}\left(\mathrm{C}_{24} \mathrm{H}_{24}\right)\right]^{+}$in the gas phase was suggested.

\section{Experimental}

[2.2.2]Paracyclophane (puriss., $\geq 99 \%$ ) was purchased from Aldrich, while rubidium chloride (puriss., $\geq 99 \%$ ), $\mathrm{RbCl}$, was supplied by Fluka. Other chemicals used (Lachema, Brno, Czech Republic) were of reagent grade purity. In this context it should be stated that rubidium has two stable isotopes, i.e., ${ }^{85} \mathrm{Rb}$ (natural abundance: $72.168 \%$ ) and ${ }^{87} \mathrm{Rb}$ (natural abundance: $27.832 \%$ ).

The mass spectra were measured on the $3200 \mathrm{Q}$ TRAP (AB Sciex, Canada) mass spectrometer. This instrument was equipped with an electrospray ion source. The experiments were carried out in a positive-ion mode. Nitrogen was used as a nebulizer gas. The operating conditions for the mass spectrometer were set as follows: ionspray voltage $5.5 \mathrm{kV}$; curtain gas 10 arbitrary units, ion source gas(1) 18 arbitrary units and ion source gas(2) 0 arbitrary units; ion source temperature ambient; declustering potential $35 \mathrm{~V}$ and entrance potential $10 \mathrm{~V}$. Mass spectra were recorded from $\mathrm{m} / z 100$ to 800 . A mixture of
[2.2.2] paracyclophane $\left(8 \times 10^{5} \mathrm{~mol} / \mathrm{L}\right)$ and $\mathrm{RbCl}\left(2 \times 10^{-3}\right.$ $\mathrm{mol} / \mathrm{L})$ dissolved in methanol/chloroform (1:1) was introduced into the ESI source via a PEEK capillary at a flow rate of $10 \mu \mathrm{L} / \mathrm{min}$.

\section{Results and Discussion}

\section{1. Electrospray Ionization Mass Spectrometry}

Figure 2 depicts an ESI mass spectrum measured in a positive-ion mode for a mixture of [2.2.2] paracyclophane $\left(\mathrm{C}_{24} \mathrm{H}_{24}\right)$ with $\mathrm{RbCl}$ in a methanol/chloroform (1:1) solution. The intense peaks in the mass spectrum at $\mathrm{m} / \mathrm{z}$ 397 and 399 evidently belong to the cationic complex $\left[\mathrm{Rb}\left(\mathrm{C}_{24} \mathrm{H}_{24}\right)\right]^{+}$. Besides, two insets in Figure 2 represent the real and calculated isotope patterns of the cationic cluster $\left[\mathrm{Rb}\left(\mathrm{C}_{24} \mathrm{H}_{24}\right)\right]^{+}$related to the presence of two stable isotopes of rubidium, i.e., ${ }^{85} \mathrm{Rb}$ and ${ }^{87} \mathrm{Rb}$, in natural abundances 72.168 and $27.832 \%$, respectively. It is necessary to emphasize that under the present experimental conditions, the cationic complex species $\left[\mathrm{Rb}\left(\mathrm{C}_{24} \mathrm{H}_{24}\right)\right]^{+}$was proven in the gas phase. No other [2.2.2] paracyclophane complexes with $\mathrm{Rb}^{+}$were found by using this experimental method.

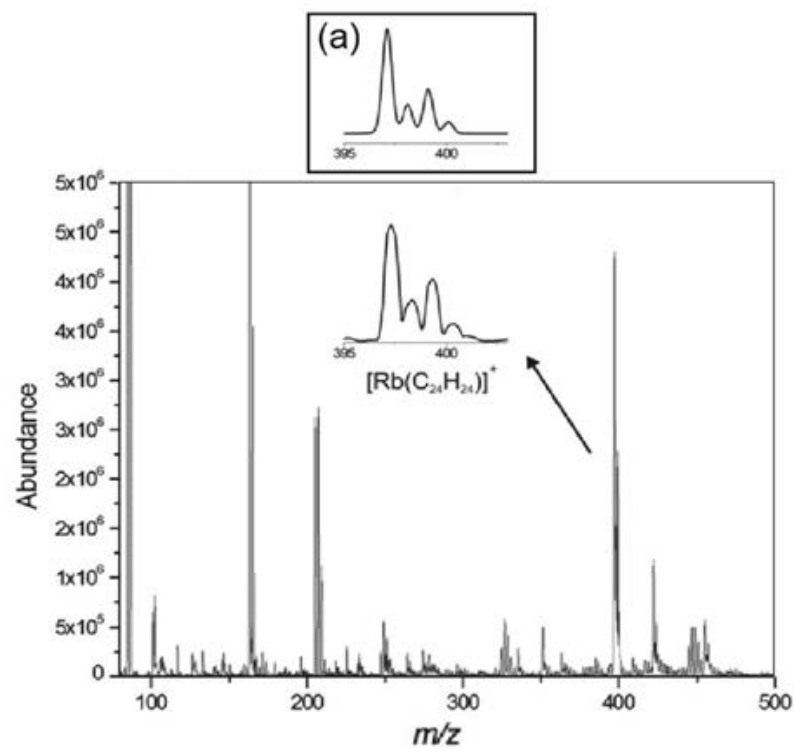

Figure 2. Positive-ion mode ESI mass spectrum of a mixture of [2.2.2]paracyclophane $\left(8 \times 10^{5} \mathrm{~mol} / \mathrm{L}\right)$ with $\mathrm{RbCl}\left(2 \times 10^{-3} \mathrm{~mol} / \mathrm{L}\right)$ in methanol/chloroform (1:1). The inset shows the real isotope pattern of the $\left[\mathrm{Rb}\left(\mathrm{C}_{24} \mathrm{H}_{24}\right)\right]^{+}$complex on an expanded mass scale. The inset (a) provides the calculated isotope pattern of the considered $\left[\mathrm{Rb}\left(\mathrm{C}_{24} \mathrm{H}_{24}\right)\right]^{+}$complex.

Furthermore, Figure 3a shows a collision induced dissociation (CID) mass spectrum of the ions $\left[{ }^{85} \mathrm{Rb}\left(\mathrm{C}_{24} \mathrm{H}_{24}\right)\right]^{+}(m / z 397)$, where the only one significant fragment ion signal was found at $m / z 85$. Analogously, in a 
CID mass spectrum of $\left[{ }^{87} \mathrm{Rb}\left(\mathrm{C}_{24} \mathrm{H}_{24}\right)\right]^{+}$given in Figure $3 \mathrm{~b}$, the sole fragment ions at $m / z 87$ were observed. These facts clearly indicate that the only significant fragmentation channel in the investigated complex $\left[\mathrm{Rb}\left(\mathrm{C}_{24} \mathrm{H}_{24}\right)\right]^{+}$is the loss of one electroneutral [2.2.2]paracyclophane ligand, similarly as in our recent paper. ${ }^{23}$
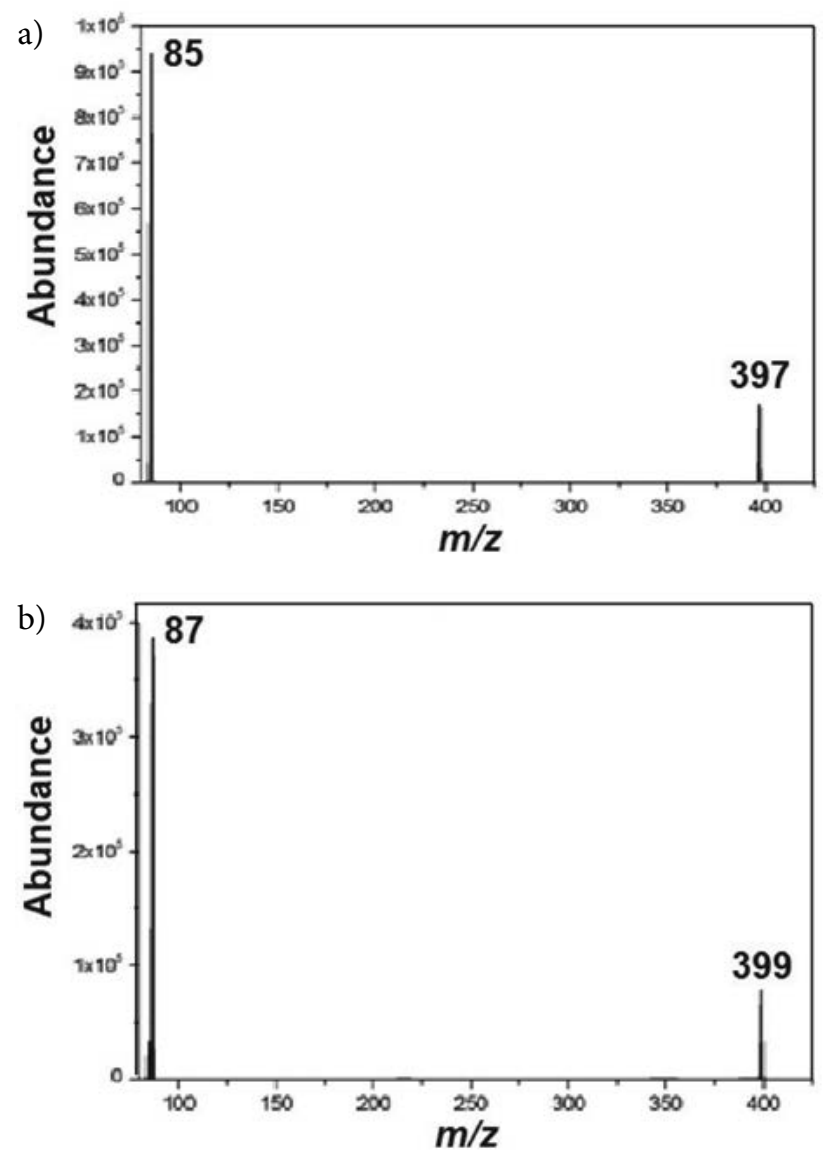

Figure 3. CID mass spectra of (a) $\left[{ }^{85} \mathrm{Rb}\left(\mathrm{C}_{24} \mathrm{H}_{24}\right)\right]^{+}$and (b) $\left[{ }^{87} \mathrm{Rb}\left(\mathrm{C}_{24} \mathrm{H}_{24}\right)\right]^{+}$ions obtained with nitrogen $\left(1 \times 10^{-2} \mathrm{mbar}\right)$ at collision energy of $15 \mathrm{eV}$ (laboratory frame).

In summary, we have evidenced experimentally that the cationic complex $\left[\mathrm{Rb}\left(\mathrm{C}_{24} \mathrm{H}_{24}\right)\right]^{+}$must be present in the gas phase, and when the mentioned complex is collisionally activated, it decomposes almost exclusively via elimination of the electroneutral [2.2.2] paracyclophane molecule (i.e., $\mathrm{C}_{24} \mathrm{H}_{24}$ ), while the charge is retained on the rubidium atom in the form of $\mathrm{Rb}^{+}$.

\section{2. Quantum Chemical DFT Calculations}

The theoretical calculations were performed at the density functional level of theory by using modern hybrid $\omega$-B97XD functional including long range and dispersion corrections, ${ }^{25}$ employing the Gaussian 09 suite of programs. ${ }^{26}$ Modern balanced def2-TZVP basis set $^{27}$ was used, and the optimizations were unconstrained. In order to increase the numerical accuracy and to reduce oscillations during the molecular geometry optimization, two-electron integrals and their derivatives were calculated by using the pruned $(99,590)$ integration grid, having 99 radial shells and 590 angular points per shell. This was ensured by means of the Gaussian 09 keyword "integral(ultrafinegrid)".

The most probable conformation of the $\left[\mathrm{Rb}\left(\mathrm{C}_{24} \mathrm{H}_{24}\right)\right]^{+}$ cationic complex was predicted on the basis of the thorough conformational analyses (i. e., eight very different initial mutual positions of the [2.2.2]paracyclophane ligand and the $\mathrm{Rb}^{+}$cation were considered during the geometry optimization) and the respective vibrational frequency analyses, analogously as in our articles. ${ }^{28-32}$

During the model calculations, the molecular geometries of the free [2.2.2] paracyclophane ligand and its cation- $\pi$ complex with $\mathrm{Rb}^{+}$were optimized, similarly as in our previous papers. ${ }^{28-32}$ The optimized conformation of this free [2.2.2] paracyclophane, having a symmetry very close to $C_{3}$, is given in Figure 4 .

Furthermore, we must emphasize that the only conformation was obtained by the full DFT optimization of the [2.2.2]paracyclophane $-\mathrm{Rb}^{+}$complex (i.e., $\left.\left[\mathrm{Rb}\left(\mathrm{C}_{24} \mathrm{H}_{24}\right)\right]^{+}\right)$, which is shown in Figure 5. It should be
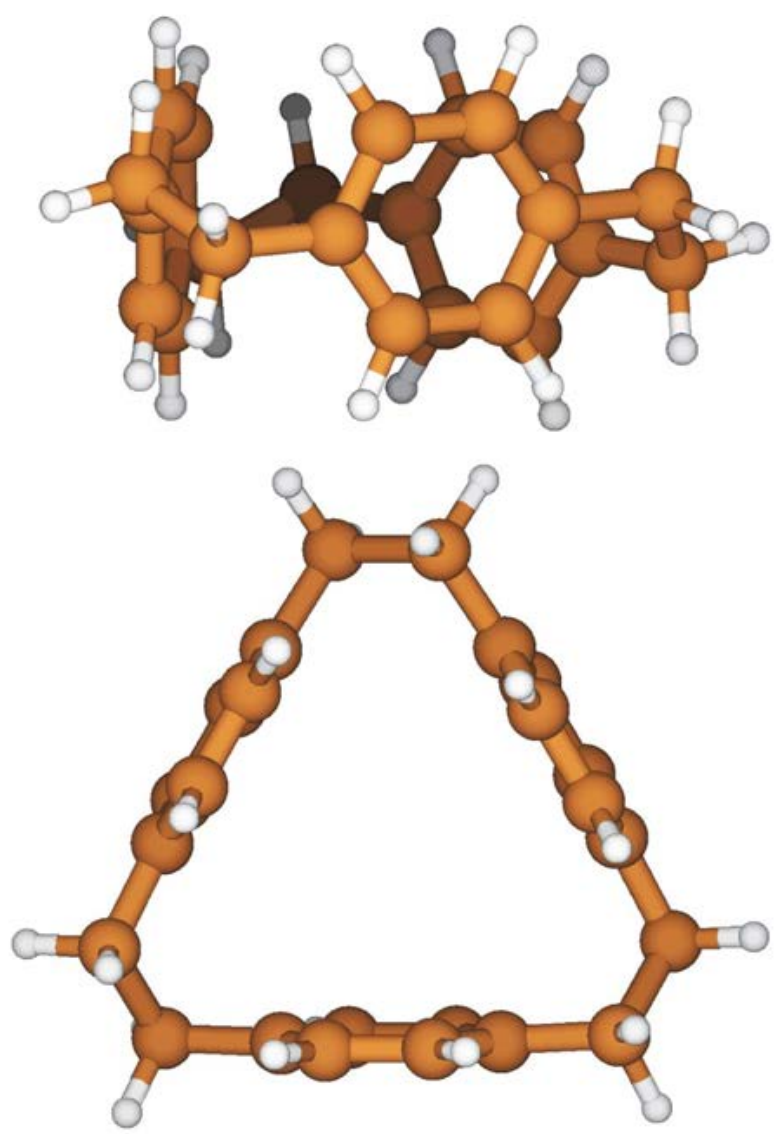

Figure 4. Two projections of the DFT optimized structure of free [2.2.2] paracyclophane ( $\omega$-B97XD / def2-TZVP). 
stated that the respective vibrational calculations found no imaginary frequencies. In the cationic complex $\left[\mathrm{Rb}\left(\mathrm{C}_{24} \mathrm{H}_{24}\right)\right]^{+}$with a symmetry very close to $C_{3}$ as well, the "central" cation $\mathrm{Rb}^{+}$, fully located in the cavity of the parent [2.2.2] paracyclophane ligand, is coordinated to all three benzene rings of [2.2.2] paracyclophane via cation- $\pi$ interaction (the distances between the "central" cation $\mathrm{Rb}^{+}$ and the centroids of the three benzene rings are 2.88, 2.88, and $2.88 \AA$ ), as also presented in detail in Figure 5. Further conformation of the $\left[\mathrm{Rb}\left(\mathrm{C}_{24} \mathrm{H}_{24}\right)\right]^{+}$complex was not found by using the above-mentioned theoretical procedure. Besides, from comparison of Figure 4 with Figure 5, it is obvious that the inclusion of the rubidium cation causes a slight deformation of the ligand molecule in the considered $\left[\mathrm{Rb}\left(\mathrm{C}_{24} \mathrm{H}_{24}\right)\right]^{+}$complex. It must be pointed out that encapsulation of light alkali metal cation $\mathrm{Na}^{+}$do not cause any deformation of the mentioned [2.2.2] paracyclophane ligand (see Figure 6). ${ }^{24}$

Finally, the binding energy, $E($ int), of the $\left[\mathrm{Rb}\left(\mathrm{C}_{24} \mathrm{H}_{24}\right)\right]^{+}$complex, involving the 7 point correction for the basis set superposition error (BSSE), ${ }^{33,34}$ was calculated as $-99.3 \mathrm{~kJ} / \mathrm{mol}$. Recently, the binding energy of the
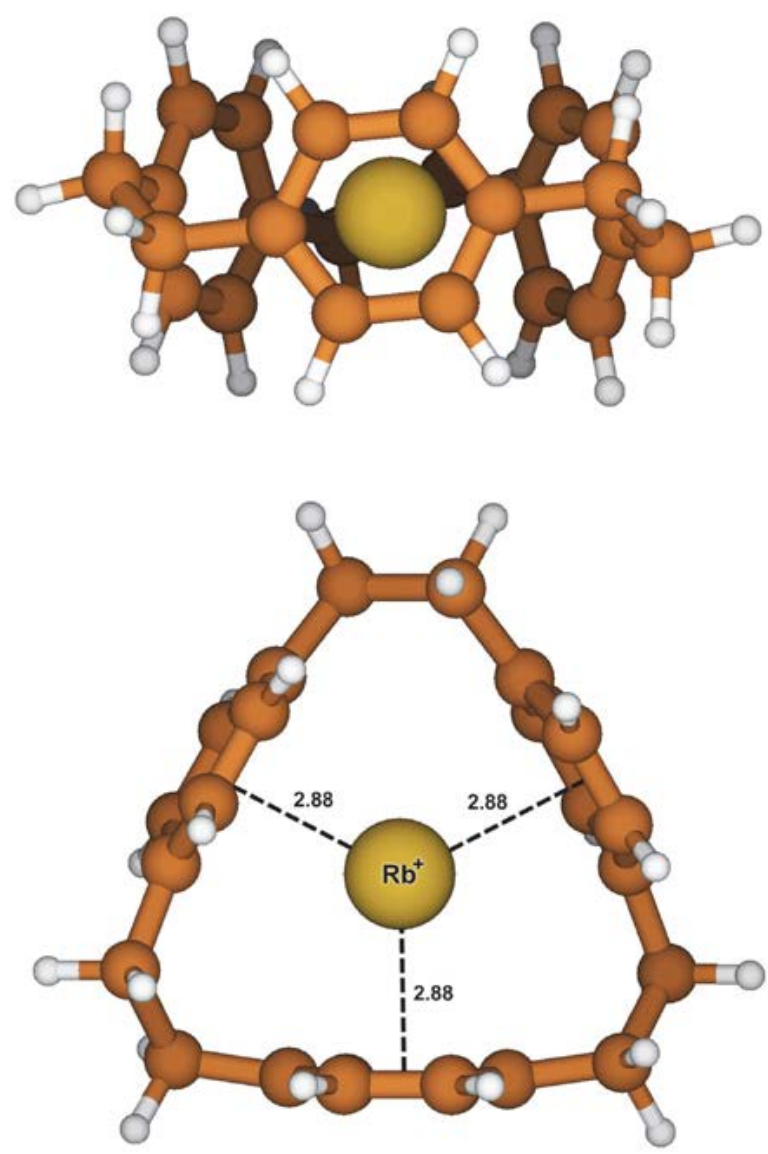

Figure 5. Two projections of the DFT optimized structure of the $\left[\mathrm{Rb}\left(\mathrm{C}_{24} \mathrm{H}_{24}\right)\right]^{+}$complex ( $\omega$-B97XD / def2-TZVP); the distances between the "central" cation $\mathrm{Rb}^{+}$and the centroids of the three benzene rings are $2.88,2.88$, and $2.88 \AA$.

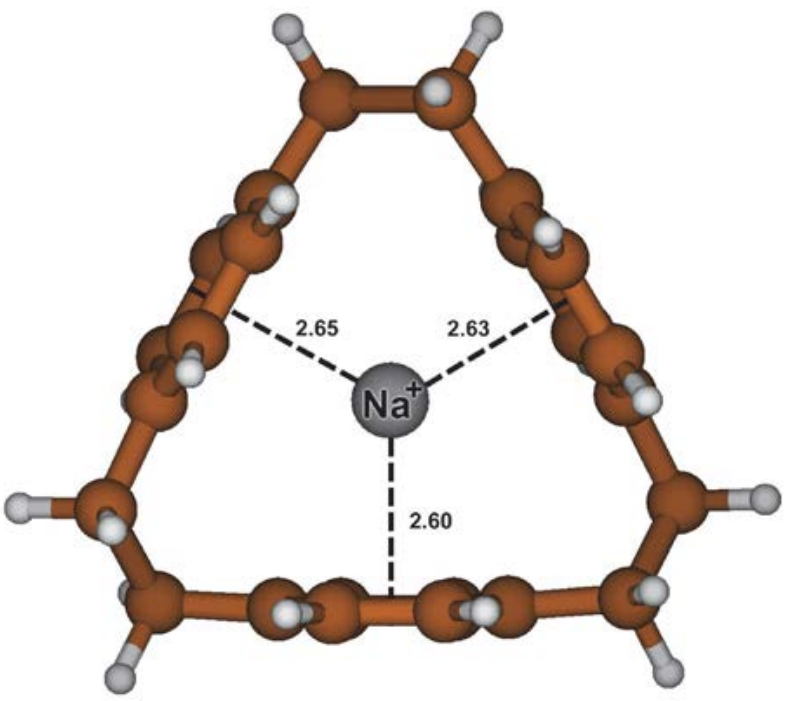

Figure 6. DFT optimized structure of the $\left[\mathrm{Na}\left(\mathrm{C}_{24} \mathrm{H}_{24}\right)\right]^{+}$complex $(\omega$-B97XD / def2-TZVP); the distances between the "central" cation $\mathrm{Na}^{+}$and the centroids of the three benzene rings are $2.65,2.63$, and $2.60 \AA$ (Ref. ${ }^{24}$ ).

complex [2.2.2]paracyclophane $-\mathrm{Tl}^{+}$(i.e., $\left.\left[\mathrm{Tl}\left(\mathrm{C}_{24} \mathrm{H}_{24}\right)\right]^{+}\right)$ in the gas phase has been determined as $-198.1 \mathrm{~kJ} / \mathrm{mol}^{23} \mathrm{It}$ means that the stability of the investigated complex $\left[\mathrm{Rb}\left(\mathrm{C}_{24} \mathrm{H}_{24}\right)\right]^{+}$in the gas phase is substantially lower than that of the mentioned $\left[\mathrm{Tl}\left(\mathrm{C}_{24} \mathrm{H}_{24}\right)\right]^{+}$complex species, although the deformation of the ligand, caused by an inclusion of the $\mathrm{Tl}^{+}$cation is even higher, than in the case of the $\mathrm{Rb}^{+}$cation. ${ }^{23}$ This is evidently caused by the higher "softness" of $\mathrm{Tl}^{+}$in comparison with $\mathrm{Rb}^{+}$.

\section{Conclusions}

In this work, we have shown that an experimental (ESI-MS) and theoretical (DFT calculations) approach can provide important information concerning the noncovalent binding interaction between the electroneutral [2.2.2] paracyclophane ligand and the univalent rubidium cation $\left(\mathrm{Rb}^{+}\right)$in the gas phase. On the basis of the mentioned experimental method, the cationic complex $\left[\mathrm{Rb}\left(\mathrm{C}_{24} \mathrm{H}_{24}\right)\right]^{+}$ was evidenced quite unambiguously. In addition, employing DFT calculations, the most probable conformation of this fascinating rubidium(I) complex was suggested. In the resulting complex $\left[\mathrm{Rb}\left(\mathrm{C}_{24} \mathrm{H}_{24}\right)\right]^{+}$with a symmetry very close to $C_{3}$, the "central" cation $\mathrm{Rb}^{+}$, fully located in the cavity of the parent [2.2.2] paracyclophane ligand, is coordinated to all three benzene rings of [2.2.2]paracyclophane via cation- $\pi$ interaction. It means that [2.2.2]paracyclophane can be considered as a receptor for the rubidium cation in the gas phase. As follows from the previous facts, the present work may be a significant contribution especially to both experimental and theoretical study of [2.2.2]paracyclophane, as well as to structural chemistry in general. 


\section{Acknowledgements}

This work was supported by the Grant Agency of Faculty of Environmental Sciences, Czech University of Life Sciences, Prague, Project No.: 42900/1312/3114 entitled "Environmental Aspects of Sustainable Development of Society", as well as by the Czech Ministry of Education, Youth, and Sports (Project MSMT No.: 20/2015).

\section{References}

1. Comprehensive Supramolecular Chemistry, vol. 1, edited by J. L. Atwood, J. E. D. Davis, D. D. MacNicol, F. Vögtle, Pergamon, Oxford, UK, 1996.

2. F. Vögtle, S. Ibach, M. Nieger, C. Chartroux, T. Krüger, H. Stephan, K. Gloe, Chem. Commun. 1997, 1809-1810.

DOI:10.1039/A703715E

3. J. L. Pierre, P. Baret, P. Chautemps, M. Armand, J. Am. Chem. Soc. 1981, 103, 2986-2988. DOI:10.1021/ja00401a013

4. J. Gross, G. Harder, A. Siepen, J. Harren, F. Vögtle, H. Stephan, K. Gloe, B. Ahlers, K. Cammann, K. Rissanen, Chem. Eur. J. 1996, 2, 1585-1595. DOI:10.1002/chem.19960021218

5. E. G. Buchanan, J. C. Dean, T. S. Zwier, E. L. Sibert III, J. Chem. Phys. 2013, 138, 064308/1-064308/11.

DOI: $10.1063 / 1.4790163$

6. A. O. Ortolan, G. F. Caramori, G. Frenking, A. Muñoz-Castro, New J. Chem. 2015, 39, 9963-9968.

DOI:10.1039/C5NJ02384J

7. D. A. Dougherty, Science 1996, 271, 163-168. https://www.ncbi.nlm.nih.gov/pubmed/8539615

8. A. S. Mahadevi, G. N. Sastry, Chem. Rev. 2013, 113, 21002138. DOI:10.1021/cr300222d

9. J. C. Ma, D. A. Dougherty, Chem. Rev. 1997, 97, 1303-1324. DOI:10.1021/cr9603744

10. K. S. Kim, P. Tarakeshwar, J. Y. Lee, Chem. Rev. 2000, 100, 4145-4185. DOI:10.1021/cr990051i

11. N. Zacharias, D. A. Dougherty, Trends Pharm. Sci. 2002, 23, 281-287. https://www.ncbi.nlm.nih.gov/pubmed/12084634

12. G. W. Gokel, Chem. Commun. 2003, 2847-2852. DOI:10.1039/b305483g

13. D. Schröder, H. Schwarz, J. Hrušák, P. Pyykkö, Inorg. Chem. 1998, 37, 624-632. DOI:10.1021/IC970986M

14. A. Gapeev, C.N. Yang, S. J. Klippenstein, R. C. Dunbar, J. Phys. Chem. A 2000, 104, 3246-3256. DOI:10.1021/jp992627d

15. S. Tsuzuki, M. Yoshida, T. Uchimaru, M. Mikami, J. Phys. Chem. A 2001, 105, 769-773. DOI:10.1021/jp003287v

16. H. Huang, M. T. Rodgers, J. Phys. Chem. A 2002, 106, 42774289. DOI:10.1021/jp013630b

10. Y. Mo, G. Subramanian, J. Gao, D. M. Ferguson, J. Am. Chem. Soc. 2002, 124, 4832-4837. DOI:10.1021/ja0174433

18. A. S. Reddy, G. N. Sastry, J. Phys. Chem. A 2005, 109, 88938903. DOI:10.1021/jp0525179
19. D. Vijay, G. N. Sastry, Phys. Chem. Chem. Phys. 2008, 10, 582-590. DOI:10.1039/B713703F

20. K. Sakurai, T. Mizuno, H. Hiroaki, K. Gohda, J. Oku, T. Tanaka, Angew. Chem., Int. Ed. Engl. 2005, 44, 6180-6183.

DOI:10.1002/anie.200500806

21. C. Cohen-Addad, P. Baret, P. Chautemps, J. L. Pierre, Acta Crystallogr., Sect. C: Cryst. Struct. Commun. 1983, C39, 13461349. DOI:10.1107/S0108270183008483

22. P. G. Jones, P. Bubenitschek, F. Heirtzler, H. Hopf, Acta Crystallogr., Sect. C: Cryst. Struct. Commun. 1996, C52, 1380 1384. DOI: $10.1107 /$ S0108270195017008

23. E. Makrlík, S. Böhm, D. Sýkora, B. Klepetářová, P. Vaňura, M. Polášek, Chem. Phys. Lett. 2015, 642, 39-42.

DOI:10.1016/j.cplett.2015.10.074

24. E. Makrlík, D. Sýkora, S. Böhm, P. Vaňura, J. Mol. Struct. 2018, 1154, 79-82. DOI:10.1016/j.molstruc.2017.10.027

25. J.-D. Chai, M. Head-Gordon, Phys. Chem. Chem. Phys. 2008, 10, 6615-6620. DOI:10.1039/b810189b

26. M. J. Frisch, G. W. Trucks, H. B. Schlegel, G. E. Scuseria, M. A. Robb, J. R. Cheeseman, G. Scalmani, V. Barone, B. Mennucci, G. A. Petersson, H. Nakatsuji, M. Caricato, X. Li, H. P. Hratchian, A. F. Izmaylov, J. Bloino, G. Zheng, J. L. Sonnenberg, M. Hada, M. Ehara, K. Toyota, R. Fukuda, J. Hasegawa, M. Ishida, T. Nakajima, Y. Honda, O. Kitao, H. Nakai, T. Vreven, J. A. Montgomery, Jr., J. E. Peralta, F. Ogliaro, M. Bearpark, J. J. Heyd, E. Brothers, K. N. Kudin, V. N. Staroverov, R. Kobayashi, J. Normand, K. Raghavachari, A. Rendell, J. C. Burant, S. S. Iyengar, J. Tomasi, M. Cossi, N. Rega, J. M. Millam, M. Klene, J. E. Knox, J. B. Cross, V. Bakken, C. Adamo, J. Jaramillo, R. Gomperts, R. E. Stratmann, O. Yazyev, A. J. Austin, R. Cammi, C. Pomelli, J. W. Ochterski, R. L. Martin, K. Morokuma, V. G. Zakrzewski, G. A. Voth, P. Salvador, J. J. Dannenberg, S. Dapprich, A. D. Daniels, Ö. Farkas, J. B. Foresman, J. V. Ortiz, J. Cioslowski, D. J. Fox, Gaussian 09, Revision C.01. Gaussian Inc., Wallingford, CT (2009).

27. F. Weigend, R. Ahlrichs, Phys. Chem. Chem. Phys. 2005, 7, 3297-3305. DOI:10.1039/b508541a

28. J. Kříž, J. Dybal, E. Makrlík, P. Vaňura, B. A. Moyer, J. Phys. Chem. B 2011, 115, 7578-7587. DOI:10.1021/jp203221k

29. E. Makrlík, P. Vaňura, R. Rathore, Monatsh. Chem. 2015, 146, 521-525. DOI:10.1007/s00706-014-1370-y

30. E. Makrlík, P. Vaňura, Mol. Phys. 2015, 113, 3712-3716. DOI:10.1080/00268976.2015.1054326

31. E. Makrlík, S. Böhm, P. Vaňura, P. Ruzza, Mol. Phys. 2015, 113, 1472-1477. DOI:10.1080/00268976.2015.1006276

32. E. Makrlík, J. Kvíčala, P. Vaňura, Mol. Phys. 2016, 114, $2046-$ 2051. DOI:10.1080/00268976.2016.1177221

33. L. Turi, J. J. Dannenberg, J. Phys. Chem. 1993, 97, 2488-2490. DOI:10.1021/j100113a002

34. J. E. Rode, J. C. Dobrowolski, Chem. Phys. Lett. 2002, 360, 123-132. DOI:10.1016/S0009-2614(02)00779-0 


\section{Povzetek}

$\mathrm{Z}$ uporabo elektrosprej ionizacijske masne spektrometrije (ESI-MS) smo dokazali, da rubidijev kation $\left(\mathrm{Rb}^{+}\right) \mathrm{z}$ elektronevtralnim [2.2.2] paraciklofanskim ligandom $\left(\mathrm{C}_{24} \mathrm{H}_{24}\right)$ tvori kationski kompleks $\left[\mathrm{Rb}\left(\mathrm{C}_{24} \mathrm{H} 24\right)\right]^{+}$. S pomočjo kvantno-kemijskih izračunov smo določili tudi najbolj verjetno konformacijo tega kompleksa. Ugotovili smo, da ima simetrijo zelo blizu C3, da je „osrednji“ kation $\mathrm{Rb}^{+} \mathrm{v}$ celoti umeščen v prostor matičnega [2.2.2]paraciklofanskega liganda, in koordiniran $z$ vsemi tremi benzenskimi obroči [2.2.2] paraciklofana preko kation- $\pi$ interakcije. Ocenili smo energijo vezave, $\mathrm{E}(\mathrm{int})$, obravnavanega kation- $\pi$ kompleksa $\left[\mathrm{Rb}\left(\mathrm{C}_{24} \mathrm{H}_{24}\right)\right]^{+}$. Vrednost $-99,3 \mathrm{~kJ} / \mathrm{mol}$ potrjuje verjetnost nastanka tega zanimivega kompleksa, kar pomeni, da [2.2.2]paraciklofanski ligand lahko obravnavamo kot receptor $\mathrm{Rb}^{+} \mathrm{v}$ plinski fazi. 